\title{
Political Movement By Apolitical Activist: Gezi Park Protests
}

\author{
Ferihan Polat, Assistant Prof. \\ Ozlem Ozdesim Subay, PhD Candidate
}

Pamukkale University, Turkey

doi: 10.19044/esj.2016.v12n8p106 URL:http://dx.doi.org/10.19044/esj.2016.v12n8p106

\begin{abstract}
Gezi Park Protests leaving its mark in the June of 2015, is understood from so many perspectives by national and international academicians. On the one hand, some social scientists recognize this movement as apolitical action by analyzing the identity of activist, on the other hand, some of them claims that this movement is a political one by pointing out that the aim of the movement is against the Ak Party Government especially Erdoğan himself. This study aiming to understand Gezi Park Protests puts forward that having apolitical identity of activists is not enough to recognize the movement as apolitical one and also claiming that having political action cannot be explained by the idea that the movement is just against the Ak Party Government. This study justifying that this movement cannot be explained by the idea of domestic political conflict and separation as Turkey is a part of global capitalist order, focuses on dimensions of crossing national borders. Beyond the evaluation of Gezi Park Protests as an international conspiracy, interpretation of this movement as a part of the growing public protests against the system on a global scale is a more plausible perspective to understand the multidimensional social reality.
\end{abstract}

Keywords: Gezi Park Protests, Crisis of Neo-liberalism, Social Class, AntiCapitalist Resistance

\section{Introduction}

Gezi Park Protests began at night on 27 May 2013 with the aim of protest against the Taksim Square Pedestrianization Project by gathering together 50 demonstrators at Gezi Park. These demonstrators were defending that the construction around the park was illegal and after they prevented workers from doing their jobs, they decided to vigil at Gezi Park in order not to work their machines again. Since the night of 28th May the demonstrators at Gezi Park had stated that they were opposed to not only the 
Pedestrianization Project in Taksim Square but also urban transformation projects exercised in İstanbul especially in Beyoğlu. After decision of guard duty, breaking moment putting national public agenda to demonstrators developed on 29th May with the effort of police teams for ending the protests by removing demonstrators the outside of Gezi Park. With this effort some police teams started to set on fire the tents of demonstrators and this situation created a great impact in social media in a short notice. The intervention of police teams had been mobilized some politicians by supporting the demonstrators. BDP İstanbul Deputy Sırrı Süreyya Önder stopped the construction workers once again for pedestrianization project by preventing from construction machine after burning tents. At that day, the deputies of Republican People Party visited Gezi Park for supporting to the demonstrators. The conflict between police teams and demonstrators reached its peak at the night of 31th May. In the first days of the protests, police forces were failed to end the conflict and the violence at the streets spread across the country, therefore government understood this wasn't a simple security problem (Ete ve Taştan, 2013, s:21-29).

Due to the fact that protests in the street caused violence and intense clashes, Ak Party government, as aimed by demonstrators, reacted fiercely. Prime Minister Erdoğan identified protests as political and ideological movement against the Ak Party Government. The main opposition party, RPP, canceled its meeting at the Kadıköy Square and asked party members to come to Taksim Square to support the protests that affected the government reaction about identifying Gezi Park Protests as against them. Government tried to have direct conversation with demonstrators on 5th June and the Deputy Prime Minister Bülent Arınç came together with Taksim Cooperation Platform to listen their demands. Representatives of demonstrators asked for remaining Gezi Park as a park, dismissal of some policemen responsible from disproportionate force during the protests, prohibition of using gas bomb and suchlike materials, the release of detainees and making no investigation about them. They also asked from the government to use all squares especially Taksim and Kizilay and public spaces for meetings and demonstrations without actual prohibition and prevention on 1 May. After the meeting with government, Prime Minister Erdoğan came together with the representatives of demonstrators on 12th June (Ete ve Taştan, 2013, s:21-29). After the meeting with Erdoğan, Erdoğan accepted to wait for adjudication and agreed that if it is positive for demonstrators, government would implement the decision of judiciary; if it is negative for demonstrators, there would be referendum and government would implement the decision of public. After this statement of Prime Minister, some demonstrators decided to end their protests and some of them continued their protests at public parks (MAZLUM-DER, 2013: 4). 
These developments after 5th June changed the approach to Ak Party Government had criticized as not having any dialog with demonstrators and ignoring the demands of them. In this process, the perception about demonstrators being indifferent to positive towards attitude of government, had strengthened in the public opinion and changed the level of legitimacy of Gezi Park Protests. In addition to this, the statement of Erdoğan about protests that demonstrators didn't actually support the environmentalism and this protests were doing against his personality and Ak Party, made voters of Ak Party show their support to Erdoğan who is also criticized harshly by foreign countries. At this moment, Ak Party started to have some series of meetings called as "Respect for National Will" in order to indicate how still popular they are in public and how hard abolish their government. By these meetings, Prime Minister Erdoğan tested the public support to his government and proved that some negative perception towards them during Gezi Park Protests didn't reflect the reality (Ete ve Taştan, 2013, s:21-29).

During the Gezi Park Protests, participants consisted of people who has different priorities and the aims of protests became more comprehensive than the beginning, therefore it wasn't just a protest against reorganization of a park. This quick transformation also had changed the approach of the government towards protests. Police teams interfered the protests, continuing two weeks without any interruption, and cleared the park on the night of 15th June 2013, which was a breaking point for Gezi Park Protests. It can be interfered that by losing the Gezi Park as a symbol of protests across the country, social opposition movement began to lose its support and forced to revise the aim of protests. The demonstrators who didn't achieve their goals with street protests changed their methods by keeping a distance from violence and they started to have neighborhood meetings and independent election campaign in a peaceful way. Developments after 15th June not only caused the transformation of protests but also caused to weaken the interest of public to the protest. At the night of 15th June, police forces took control over Gezi Park and government initiated gardening and landscaping in the park (Ete ve Taştan, 2013, s:21-29).

To sum up, in the period of 31st May and 15th June, Gezi Park Protests turned into street violence and clashes; protests began in Gezi Park had quickly spread across the country. Alpman claimed that Gezi Park Protests has three processes called as; the appeal process, the process of rebellion and resistance process. The first process is the appeal process that consists of objection of a group of people who has different demands from government about Gezi Park and this objection was accepted by city residents. The second process is the process of rebellion which is disproportionate police intervention against demonstrators in order to end the appeal process by resulting in transformation into resistance process. The last 
one is resistance process which this rebellion spread across the country by turning into a general uprising. On the other hand, with resistance process by turning into a general uprising, demands of demonstrators about Gezi Park had changed into socio-political demands and criticism of the system in Turkey. These socio-political demands provided a new integrative platform for someone who couldn't find a political environment to express their demands called as apolitical and someone who is also political. On the other hand, resistance process arising against fierce police intervention is a different political experience for Turkish history by reinforcing political sensitivity and acquiring a critical aspect of politicization (Alpman, 2013: 380).

\section{Political Aim of Gezi Park Protests}

In social science literature, there are two different evaluations about Gezi Park Protests in accordance with aim, motives and forms of action. The first evaluation adopts the idea that Gezi Park Protests is planned by external forces that doesn't like the success of Turkey in respect of development. This evaluation is also expressed by Prime Minister Erdoğan frequently in his speeches and meetings and according to him, this uprising is a movement to overthrow Prime Minister Erdoğan himself and Ak Party government in order to undermine the stability of Turkey (Polat, 2015: 98).

One of the most essential resources supporting this evaluation by taking the government side against Gezi events is prepared by Institute of Strategic Thinking called as "Taksim Gezi Park Events". This report claim that Gezi Park Protests is an "international conspiracy" since from the beginning the aim of this movement is organizing a rebellion across the country beyond the Gezi Park. The report argue that the rebellion attempt is also tested in METU in satellite launch ceremony of TUBITAK and in Reyhanlı before Gezi Park, however this attempt has more success due to environmental awareness and urban sensibility by combining the accumulated anger against Ak Party (SDE, 2013: 5).

The evaluation of Gezi Park Protests based on only against AK Party government and Erdoğan himself is problematic since this evaluation ignores so many social reality in many dimensions. Moreover, the second evaluation against the first one, focuses on the idea that Gezi Park Protests is a movement against capitalism, it's production of anti-democratic conservative government and the implementations of this government. This antidemocratic conservative government expands its power in every day by interfering private lives of individuals, therefore some social groups supporting the gains of modernization and laicism show reaction against this intervention in order not to lose these gains. The political and cultural perspective of Gezi Park Protests make social contradictions visible is a 
criticism of bourgeoisie in accordance with authoritarian and conservative government supported by bourgeoisie. Since 2000s, bourgeoisie has choose or has to choose to support a conservative government who has produced Islamist motives in political discourses and reflected this ideas in implementations of government, which creates anger that directed to government in some social groups.

\section{Characteristics of Social Classes in Gezi Park Protests:}

Gezi Park Protests is considered as one of the most essential political movement in Turkish political history, was initiated by a small environmentalist group to protest " Taksim Square Pedestrianization Project" in the night of 27th May 2013 and spread all over the country by pouring people into the streets. Besides, the protests doesn't only affect in this geography, has also turned into a public protest spreading globally. Consequently, in a short time, the protests takes attention it deserves in the world by national and international social scientist it has been argued that which components of present order created the reasons for the protests.

Some social scientists prefer to make analysis based on culture and identity instead of political and class-based analysis about Gezi Park Protests characterized as the first and the most effective movement of new Turkey after military domination (SETA, 2013: 76). When the neoliberal and conservative attitude by government reducing social movement in international conspiracy put aside; the dominant argument for Gezi Park Protests of liberal, left, social democrat thinkers and social scientists is focused on reformist/concrete demands about culture, life style and environment etc, of postmodern era.

In order to understand Gezi Park Protests, historical and social conditions interacted with need to take into consideration. Like every social events, Gezi Park Protests is interacted with societal relations, the nature of these relations, economy, culture and policies; as with all influenced by these, social events have impact on all processes that are influenced by, which creates bilateral interaction. Class nature of capitalist social relations influences all processes in society in a way; for this reason, Gezi Park Protests is a movement needs to be understood in the framework of social class struggle.

Insel points out that Gezi Park Protests leads to a rebellion based on class, religious, sexual and ethnic identity (Insel, 2014). Also Y1ldirım claims that in Gezi Park Protests demonstrators are mostly ordinary citizens, unorganized individuals and apolitical youth disturbed by transformation into their life styles imposed by political authority (Y1ldırım, 2013). Furthermore, Göle is considered Gezi Park Protests as a youth movement secular values and life styles embodied with, opposes the politicization of movement 
sharply. According to Göle, Gezi Park Protests can only be successful in the condition of being independent from political parties and autonomous by reinforcing democracy in society. On the other hand, whether it characterizes as a political movement itself, it wouldn't be able to reinforce the democracy in societal base (Göle, 2013).

Ayata claiming that values of patriarchal culture and societal relation are integrated with implementations of authoritarian government, states that political restrictions of freedom brings together multidimensional interventions on life styles. In this context, Ayata signifies that political authority doesn't only suppress the rights and freedoms but also imposes society to cultural identity and life styles reflecting its own cultural values in social order by taking advantage of state power. According to him, the implementations of government that interference of private life of individuals, organization of the family and determination of how people lead their lives are reasons for Gezi Park Protests causing a mass movement (Ayata, 2014: 24).

Social scientists explaining Gezi Park Protests based on social classes in the analysis of contemporary class structure claim that there is a new conflicts and antagonisms in the mediation of complicated labor-capital conflict. The class characteristics of demonstrators of Gezi Park Protests and especially argumentations about notion of "middle class" constitute fundamental structure of these studies in the literature.

Keyder supporting the idea of Gezi Park Protests produced by middle classes, points out that with capitalist development, structure of middle classes has been changed and new middle classes forming a majority of the population, are based on mostly educational status. The notion of new middle classes consists of new professions as white collar mostly created by new capitalism, new petty bourgeoisie and even some social groups in contradictory social locations. Çağlar Keyder mentions that this new middle class works in the jobs requiring education, knowledge and skills and growing steadily as a number in the population. Keyder states that this new class doesn't work as employer but in accordance with their job skills they are indispensable and rewarded for their mental labor; in this manner they need to take more responsible in the decision process. In the framework of preservation of public space and anti-authoritarianism so many different social groups in respect of sociological base are participated in Gezi Park Protests, on the other hand, Keyder specifies that the demonstrators who plays a leading role in the protests especially in Istanbul are mostly belonged to the new social middle class. The new class is mostly sensitive about individual freedom, environmental awareness and the oppressiveness of state etc (Keyder, 2012:1; Keyder, 2013). 
Aslan opposing the notion of "new middle class" characterized by Keyder, defends that this group of people who have own cultural structure, cannot generate a new social structure all because of this qualities. According to him, this group is a class layer becomes visible in the process of transformation from individual capital into class capital. In the transformation of individual capital into class capital as a result of concentration and centralization, the work of audit and management is a function doing by paid employees who has education, knowledge and skills. For this reason, the audition and management of a work doesn't create property that forms new middle class Keyder mentioning about (Aslan, 2013: 39). Boratav supports this perspective with the idea that people are doctor, lawyer, architect, engineer, financial advisor etc are using their educational skills in order to make a living in exchange of money, therefore they should be included in the category of worker as white collar in the middle class. Additionally, he also points out that the participants of protests are mostly high school and university students who are likely a few years later would be included in working class or reserve army of unemployed (Boratav, 2013). Saraçoğlu considers Gezi Park Protests as class reaction since this reaction is related with the relations of production placing in the center of an analytical plane, although it is not a reaction reflecting purely particular economic interests and concerns of certain segments of society. According to him, the condition of a movement labeled as class reaction is not related in which class most participants are included in social stratification, is related likely with whether there is social contradiction (labor-capital, capital accumulation and crisis) and how and in which direction this contradiction influence the society (Saraçoğlu, 2014).

Boratav considers Gezi Park Protests as a mature class reaction of highly qualified educated workers against mugger bourgeoisie attempting seizure the massive urban rent with political authority. By taking attention into class characteristics of Gezi Park, İnan claims that it is not adequate to explain Gezi Park as "youth" and "civil society" movement as having popular, individualistic, anti consumption features; since it is a fight for freedom against capitalists who are responsible for policies exploiting nature, human being and labor (İnal, 2013). Accordingly, Özuğurlu supporting that Gezi Park Protests initiated against the capitalization of a common shared land in the city; this resistance is a moral indignation burst against the understanding that legitimizes injustice and inequality. The neo-liberal era of capitalism recreates proletarianisation of new middle class consisting by professional groups with the mechanisms of the depreciation of job/labor and commodification of reproduction conditions. Özuğurlu, taking attention that the process called as "Çapulcu (freebooter) Rebellion has some similarities with the 68' movement, supports the idea that this movement, as an evidence 
contrary to liberal perspective separating the notion of freedom from equality, puts forward a concrete program politically. The main components of this political program are provision of freedom to cultural identities and belief, the establishment of popular sovereignty and organization of social classes independently and lastly organization on the basis of work and employment and provision of opportunities for a dignified life (Özuğurlu, 2013).

Koşar claims that Gezi Park Protests, which is characterized as anger of the urban middle class, has democratic demands which are not directly basis on socialist content; on the other hand this argument doesn't mean that Gezi Park Protests inevitably is a middle class or a bourgeoisie movement. Since, bourgeoisie as a dominant power hasn't been interested this kind of demands for a long time and democratic demands is adopted by working class and its allies. Moreover, Gezi Park Protests is a working class movement, mostly educated urban workers and young people are participated (Koşar, 2013: 11-12). Hence, Lefebvre takes attention that the capital class which determines, takes control and recreates the urban transformation in a capitalist society, recreates urban exploitation with the power of exchange value of spaces. Thus, classes who don't own any property, don't have the rights of participation in the decision making process about the town they live in. In this case, the main contradiction is between the people live in town and the people commoditize the town (Lefebvre, 2000: 63 - 181).

As Koşar (2013) points out, the reasons for Gezi Park Protests is related with neoliberal restructuring policies that increases class conflicts since 2000. Privatizations, flexible working impositions, proletarianisation of agricultural population and various usurpations of rights with Labor Law constitute the main reasons for anger of people. All these political and cultural impacts underlie with sharpening of class conflicts make people intolerant of the system (Koşar, 2013). Although, in Gezi Park Protests, voiced demands aren't directly economic, social and political demands of working class, the millions in the streets are workers and laborers of the town. It shouldn't be ignored that people who are doctor, engineer and professional workers are also included in the conceptualization of middle class as proletarianisation labor. On the other hand, the participation of young people who haven't located in labor market yet, but are candidates for inclusion of this market or reserve army of unemployed of capitalism to Gezi Park Protests can be explained by the class conflict created by capitalism.

\section{Gezi Park Protests is an Anti-Capitalist Movement:}

Social scientists using Marxist sociology while analyzing social events mostly have a tendency to explain Gezi Park Protests as segment of a 
problem tangles created by a bigger system. According to this approach, explaining Gezi Park Protests as only a social movement is not adequate to analyze all motives caused Gezi Park Protests and all consequences of this movement. Since Turkey is a country in the global network and interacting with capitalist world, it is explicit that such a great opposition can not be explained by just political conflicts inside the country.

On the contrary to approach explaining Gezi Park Protests as international conspiracy, another approach characterized Gezi Park as it has a spontaneous movement and defends that it has a far beyond meaning than criticism of practices of Ak Party government. Some social scientists interpreting this movement as a reaction to social and political order created by neoliberal economic policies, emphasize the anti-capitalist feature of movement by putting forward the class characteristics of movement. According to this approach, since 2000s, the first reason underlying of Gezi Park Protests is creation of wealth promised by neoliberal restructuring policies despite of deepening the class conflicts in Turkey. Especially in Turkish Social Science literature, many social scientists as Korkut Boratav, Ahmet Tonak, Metin Özuğurlu etc oppose the approach understanding this movement aimed at wearing down or overthrowing the government by explaining protests on the basis of identity and cultural demands (Polat, 2015: 100).

The understanding of Gezi Park Protests as an uprising against the social and political structures producing by global capitalist economy and as a part of international system is not only advocated by national academic studies but also international studies. Many social scientists as Immanuel Wallerstein, David Harvery and Adam Hanieh etc, are considered Gezi Park Protests as a part of social uprising wave in international system with Marxist sociology approach (Polat, 2015: 100).

Wallerstein doesn't explain crises in the world system based on local problems; on the contrary he claims that these crises should be understood in the integrity of the world system.

According to him, the chains of social uprisings in world system cause the loss of political and cultural supports of capitalist system. This worldwide social uprisings is an indicator of transition process. Wallerstein puts forward that since 2008 the social movements all around the world is a continuity of 1968 revolutions has not yet ended. In this framework, Wallerstein considers Gezi Park Protests as a continuation of 1968 Revolutions and the main reason for Gezi Park is the neoliberal economic structures producing by capitalist system which is a part of a chain of social uprisings recently started from Middle East to Turkey (Wallerstein, 2013).

Another social scientists defending that there is a parallelism between Arab Spring and Gezi Park Protests is also Hanieh claims that this movement 
is not just related with threes as objects. Accordingly, the destiny of these trees in Gezi Park symbolizes the protests against the neoliberal model of Ak Party permitting a special form of capitalist development. Hanieh asserts that with the nature of Ak Party, Turkish capitalism produces an extremely inadequate and polarized development all over the Middle East. Hanieh, emphasizing that the main feature of this economic development is the commoditization of all aspects of social life, remarks that the most essential aspect of this commoditization is the transition of urban built environment in Istanbul and most of the Arab countries. The transition of urban built environment can be seen as active reflection of neoliberal capitalism. For this reason, Hanieh claiming that motives of 2013 Turkish Revolt and Arab Spring has some similarities, takes attention that the uprisings can't be explained by just a reason like authoritarianism, poverty, food prices and unemployment which are related with the manner of development of capitalism in this region (Hanieh, 2013: 130-131). The neoliberal commoditization, confiscation and expropriation policies caused a chain of uprisings from Arab geography, Greece and Spain to USA which Gezi Park Protests can also be included. The chain of uprisings directly linked by crisis of neo-liberalism brings about the idea of a life beyond capitalism by making hegemonies based on the monopoly of violent more vulnerable (Doğan, 2013: 96-97).

Özdek, interpreting Gezi Park Protests as a part of popular uprising started against neoliberal policies effecting various countries in the world for the last few years, points out that evacuation of Gezi Park on 15th June with the intervention of police forces should be considered not end of the movement but a transition of a spirit that leads to direct democracy. After this evacuation of Gezi Park by police forces on 15th June, starting from the parks in İstanbul to local parks all around Turkey, forums bringing together local people initiated as resistance centers. At these forums, the local problems and the future of the movement have been discussed and new working groups are created, which is a development for the emergence of a communal life. Many of the city's parks established solidarity tables, exchange markets and libraries opened, people had shared their victuals; therefore an experiment of a "commune" in Gezi Park spread all over the country (Özdek, 2013: 113- 114). According to Kürkçü, the spirit of commune, the resistance against capitalization of urban heritage and urban land create symbol for social and political struggles for future by creating a sample for direct democracy and anti-capitalist opposition (Kürkçü, 2013: 68-69).

Harvey points out that Gezi Park Protests which can be considered as liberation movement resulting in a short time has not finished yet. For Harvey, Gezi Park is just a beginning for the future events and the first 
demand of the protests, stopping the shopping center construction, is a significant step (Görkem, 2015). Also Ünlü Gök, supporting the idea that this movement gives some clue about prompting for an approach that doesn't reflect the existing political mechanisms, claims that Gezi Park Protests is a significant experience with questioning, creative, transformative features (Ünlü Gök, 2014: 90). Although this movement is considered to end on $15^{\text {th }}$ June, after this date, the resistance in Ankara-Tuzluçayır, the protests in METU for destruction of forest by road construction, Cerrattepe Resistance against hydro-electric power plant and any other social opposition movements illustrate this spirit is continuing in other dimensions and scales.

\section{Global Scale of Gezi Park Resistance}

Recently, all around the world masses that don't have any security and lost their freedoms, show resistance against the conditions imposed by neo-liberalism in respect of economy, politics and daily life. Additionally, they launch occupy and resistance movements for opposing the dominating style of the authority as one of the indicators is conversion operation of places for the sake of surplus (Öztan, 2014: 166). From the squares of Tekel to Tahrir, Madrid to Barcelona and starting from USA sprawling to all Anglo-Saxon countries by Occupy Movements, Taksim-Gezi and Sao-Paulo, huge chain of anti-capitalist resistance movement emerge with the product of crises of neo-liberalism (Doğan, 2014: 73). Gezi Park Resistance is counted as the most essential social movement specifying the necessity of institutionalization against self-interest in democracy. According to Alpman, scales of social movements are getting globally more than nationally in every passing day and this global scale constitutes its own dynamics (Alpman, 2013: 282).

Wallerstein argues for the crisis of world system and every single action may lead some significant consequences. Accordingly, in crisis period the protests, resistance or every kind of uprisings may lead effects in the system, even may have the power to affect the world (Polat and Durmuş, 2015: 106, 108). Özkul, thinking the similarities between Gezi and other movements are depended on the possibility of new opposition by the development of information and communication technologies, affirms that Gezi Park Protests, adapted to special conditions of Turkey, is a part of a chain of resistance included Arab Spring, Indignados, Occupy Wall Street and etc in global scale (Özkul, 2014: 34). Also Ertan claims that Gezi Park Protests can't be evaluated the continuity of environmentalist movements emergent in European countries like Germany and Italy. On the other hand, after Gezi Park Protests, in Brazil some similar movements emerged; however prudent attitude of country's leaders has slowed these movements. Gezi Park Protests is supported by some protests in Brazil with explanations 
and banners in the movement, which initiates Gezi has an impact extend beyond the country in a short matter (Ertan, 2014: 73- 74).

\section{Conclusion}

This movement, participated by social actors qualified as "apolitical” that aren't associated with any traditional political party or any political leader and opposing exploitation of urban by capital, is far beyond than environmentalist or youth movement. When class characteristics of demonstrators is analyzed, the main composition consisted of a segment of society living by selling their labor, the unemployed people and youth people who may participate in unreserved army of unemployed. Consequently, Gezi Park Protests is primarily a political movement of those without the means of production and those with the power of the means of production for resisting capitalization.

In order to make an integrated assessment, the political conflicts in Turkey should be taking into consideration that she is a part of world capitalist system in the global world; otherwise, consideration of Gezi Park Protests as international conspiracy doesn't reflect the reality. The political aim of the protests is not just against the authority of Ak Party government, is more against all political and economical practices of neo-liberalism by which Ak Party represents. Consequently, when domestic and international political conflicts of Gezi Park Protests are analyzed; how capitalist economy, as the infrastructure of political environment, provides a basis for this kind of movements needs to be taken attention.

Wallerstein specifying that all societies initiated to discomforted from the unequal world created by neo-liberal economic policies, evaluated together the social uprisings in Middle East, Turkey an all other countries in the world in a global perspective instead of regional. It doesn't matter which kind of citizenship they have, American, Spanish, Arab or Turkish, peoples revolt against the inequality emerged by global capitalism. If Gezi Park Protests and Arab Spring are evaluated based on a reaction social and political structures created by neo-liberalism, instead of based on international policies; the demands of discontented people can be understood more deeply and with the policy making process to respond these demands, social consensus can be restored.

\section{References:}

Akgöz, G. \& Topal, A. (2014). Adam Hanieh ile Ortadoğu ayaklanmalarının ekonomi politiği üzerine söyleşi (An interview with Adam Hanieh about the political economy of Middle East Uprisings), Praksis, 34, 121-134.

Alpman, P. S. (2013). Gezi Parkı: Şehir hakkı tartışmaları ve sosyolojinin savunulması (Gezi Park: City rigths debate and defense of sociology), 8th 
National Sociology Conference, Muğla, 375-382. http://www.sosyolojikongresi.org/ekitap/Cilt\%203.pdf (6/06/2015).

Aslan, N. (2013). Gezi aynasında Türkiye işçi sınıfının yeni profilli ve görevler (New profile and duties of working class in Turkey in the mirror of Gezi), Türk Tabipler Birliği Mesleki Sağlık ve Güvenlik Dergisi, TemmuzAralik, 35-50.

Ayata, S. (2014). Buyurganlığa ve yasakçılığa karşı direniş: "Gezi Hareketi” (The resistance against bossiness and prohibitions: "Gezi Movement"), Gazi Üniversiteli Öğretim Üyeleri Derneği Akademik Bülten , 12 (1), 22-26.

Boratav, K.(2013, 22 June) Korkut Boratav, Gezi Direnişi'ni değerlendirdi: Olgunlaşmış bir sınıfsal başkaldırı...(Korkut Boratav analyzed the Gezi Resistance: A ripe class revolt), http://www.sendika.org/2013/06/her-yertaksim-her-yer-direnis-bu-isci-sinifinin-tarihsel-ozlemi-olan-sinirsizdolaysiz-demokrasi-cagrisidir-korkut-boratav/

Doğan, A. E. (2013). Hegemonya krizine geri dönülürken tarihsel momentin gerekleri (Necessity of historical moment in hegemony crisis), Praksis, August, 95-104.

Doğan, A. E. (2014). 21. Yüzyıl isyan hareketlerinin tarihselliği: Neoliberal çitleme dalgası, müşterekler ve yeni kamu uzamı çerçevesinde bir değerlendirme (The history of social uprisings in 21th century: Fencing neoliberal wave, joints and an analysis in the framework of new public), Praksis, 34, 57-82.

Ertan, B. (2014). Gezi Parkı Direnişi ve Yeni Türkiye (Gezi Park Protests and New Turkey), Eğitim Bilim Toplum Dergisi, 12 (47), Summer, 58-77.

Ete, H. \& Taştan, C. (2013). Kurgu ile gerçeklik arasında Gezi Eylemleri (Gezi Actions between reality and fiction), SETA.

Göle, N. (2013), Gezi: bir kamusal meydan hareketinin anatomisi (Gezi: An anatomy of a public square movement), CHP Çankaya Il Başkanlı̆̆ Gazetesi, 7. Say1. Retrieved from: http://t24.com.tr/yazarlar/nilufergole/gezi-bir-kamusal-meydan-hareketinin-anatomisi,6824

Görkem, K. (2015). David Harvey'le Gezi Direnişi'nden kapitalizme ve çelişkilere dair (With David Harvey from Gezi Resistance to capitalism and its conflicts), 04.06.2015, Retrieved from: http://t24.com.tr/k24/yazi/harvey,222.

Hanieh, A. (2013). Ortadoğu'ya dair asıl mesele, hiçbir 'sosyal demokrat' seçeneğin olmamasıdır (The main point about Middle East is that there is no social democrat option), In Özay Göztepe Eds., Gezi direnişi üzerine düşünceler (pp. 129-139), Ankara: ANK, NoteBene.

İnal, K. (2013). Gezi: Tanım, failler ve roller (Gezi: Defition, perpetrator and roles), In Kemal İnal Eds. Gezi, İsyan, Özgürlük: Sokağın Şenlikli Muhalefeti, İstanbul: IST, Ayrıntı Yayınları. 
İnsel, A. (2014). Muktedire karşı dayanışma (Solidarity against rulers), 31.05.2014, Retrieved from: http://www.radikal.com.tr/radikal2/muktedire_karsi_dayanisma-1194936. Keyder, Ç. (2012). Yeni orta sınıf (New middle class), Bilim Akademisi Derneği 179 (148), $1-4$, Retrieved from: http://bilimakademisi.org/sites/default/files/duyuru/Yeni\%20Orta\%20Sınıf.p df

Keyder, Ç. (2013), Retrieved from: http://konusakonusa.org/2013/09/05/gezi-parki-protestolari-baglamindayeni-orta-siniflar-neo-liberal-donusum-ve-yoksulluk/ (01/07/2015).

KONDA (2014), Gezi raporu: toplumun Gezi Park1 olayları algısı, Gezi Parkındakiler kimlerdi? (Gezi report: perception of society about Gezi Events, who participated Gezi?) 5 June 2014, 5-11, Retrived from: http://www.konda.com.tr/tr/raporlar/KONDA_GeziRaporu2014.pdf .

Koşar, A. (2013). Gezi direnişi, sınıf ve toplumsal hareketler (Gezi Resistance, class and social movements, Retrieved from: http://www.academia.edu/4700750/Gezi_Direni\%C5\%9Fi_s\%C4\%B1n\%C4 \%B1f_ve_toplumsal_hareketler.

Kürkçü, E. (2013). Gezi'den sonra....(After Gezi...), Haziran direnişi ve doğrudan demokrasi (June rsistance and direct democracy), In Özay Göztepe (Eds) Gezi direnişi üzerine düşünceler (pp. 67- 71), Ankara: ANK, NoteBene Yayınları.

Lefebvre, H. (2000). Right to the city, In Eleonore Kofman \& Elizabeth Lebas (Eds.) Writings on cities ,Oxford: Blackwell.

MAZLUM-DER (2013) Taksim Gezi Park1 olayları raporu (The reports of Taksim Gezi Park events), Av. Ümran Sırımsı Candemir ve Av. Mehmet İzmir, MAZLUMDER İstanbul Şubesi, Retrieved from: http://istanbul.mazlumder.org/webimage/gezi-parki-raporu-2013.pdf.

Özdek, Y. (2013). Haziran direnişi ve doğrudan demokrasi (June resistance and direct democracy), In Özay Göztepe (Eds) Gezi direnişi üzerine düşünceler (pp. 111-126), Ankara: ANK, NoteBene Yayınları.

Özkul, B. (2014). Gezi'nin küresel boyutu: ağ toplumu ve doğrudan demokrasi fikri (Global scale of Gezi: Network society and direct democracy), Birikim, 302, 34-42.

Öztan, G. G. (2014), Gezi direnişi ile kurulan otantik kamusallık ve dayanışma ruhu (Authentic publicity and solidarity spirit established by Gezi resistance), Praksis, 34, 165-180.

Özuğurlu, M. (2013) “Metin Özuğurlu, Gezi Direnişi’ni değerlendirdi: Devrime hasret kalmış insanlık ve siyasetini arayan halk sınıfları...(Metin Özuğurlu evaluated Gezi Park Resistance: Humanity starved of revolution and class of people looking for politics) 28 June 2013. Retrieved from:http://www.sendika.org/2013/06/metin-ozugurlu-gezi-direnisini- 
degerlendirdi-devrime-hasret-halkmis-insanlik-ve-siyasetini-arayan-halksiniflari/

Polat, F.(2015), Dünya sistemik krizinin bir parçası olarak Gezi Parkı Direnişi (Gezi Park protests as a part of world systemic crisis), Akademik Sosyal araştırmalar Dergisi, 3 (17), September 2015, 97-117.

Polat, F. \& Durmuş, A. (2015), Immanuel Wallerstein perspektifinde Arap Baharı (Arab Spring from the perpective of Immanuel Wallerstein), Konya: Çizgi Kitabevi.

Saraçoğlu, C. (2014), Gezi Direnişi ve müzmin orta sınıf sorunu (Gezi Resistance and chronic middle class problem), 29.01.2014, Retrieved from:http://bilimsol.org/bilimsol/blog/kenar-notlari/gezi-direnisi-vemuzmin-orta-sinif-sorunu.

SDE (2013), Taksim Gezi Parkı Eylemleri (Taksim Gezi Park Events), Stratejik Düşünce Enstitüsü, Retrived from: http://www.sde.org.tr/userfiles/file/SDE\%20Taksim\%20Gezi\%20Park\%C4 \%B1\%20Raporu\%20Haziran\%202013.pdf.

SETA (2013), 2013'te Türkiye (Turkey in 2013), In Y1lmaz Ensaroğlu, Hatem Ete, Bekir S. Gül, Erdal Tanas Karagöl \& Ufuk Ulutaş (Eds) Siyaset, ekonomi ve toplum araştırmalart vakfi, 74 .

Ünlü Gök, S. (2014) Politikayı deneyimleyen bir toplumsal hareket olarak Gezi Direnişi (Gezi Protests as social movements experiencing politics), Marmara Üniversitesi Siyasal Bilimler Dergisi, 2 (1), March 2014, 75-92.

Wallerstein, I. (2013). "Turmoil in Tunisia and Egypt: Beginning or end of the revolutions?”, Retrieved from:http://www.iwallerstein.com/turmoiltunisia-egypt-beginning-revolutions.

Yildırım, Yavuz (2013), Sosyal forum'dan öfkeliler'e (From social forum to furious ones), Ankara: ANK, İletişim Yayınları. 